\title{
KERAGAAN HAMA, PENYAKIT, DAN MUSUH ALAMI PADA BUDIDAYA PADI ORGANIK
}

\section{PERFORMANCE OF PESTS, DISEASES, AND NATURAL ENEMIES ON ORGANIC RICE CULTIVATION}

\author{
Dini Yuliani dan Sudir \\ Balai Besar Penelitian Tanaman Padi \\ Jl. Raya IX Sukamandi Subang 41256 \\ Korespondensi : diniyuliani2010@gmail.com \\ Diterima 12 Mei 2017 / Disetujui 30 Juli 2017
}

\begin{abstract}
ABSTRAK
Budidaya padi organik bertujuan meminimalkan penggunaan pupuk anorganik dan pestisida kimia, namun kenyataannya tetap tidak terlepas dari gangguan hama dan penyakit. Penelitian bertujuan untuk mengetahui keragaan hama, penyakit, dan musuh alami pada budidaya padi organik. Penelitian dilaksanakan di Screen Field BB Padi pada Musim Hujan (MH) 2015/2016 dan Musim Kemarau (MK) 2016. Rancangan penelitian yang digunakan adalah Split Plot dengan tiga ulangan. Petak utama yaitu varietas: 1). Inpari 25, 2). Inpari 33, dan 3). Sintanur. Anak petak yaitu aplikasi ekstrak daun: 1). Mindi, 2). Sirsak, 3). Mahoni, dan 4). Kontrol. Aplikasi dilakukan pada 4, 6, 8, dan 10 minggu setelah tanam (MST). Pengamatan hama, penyakit, dan musuh alami pada 5, 7, 9, dan 11 MST sebanyak 20 rumpun per plot. Hasil penelitian menunjukkan varietas dan aplikasi Daun Mindi, Sirsak dan Mahoni berpengaruh nyata pada keparahan penyakit busuk batang pada 5 dan 7 MST di MH 2015/2016. Pada musim hujan ditemukan yellowing pada varietas Inpari 25 dan Inpari 33. Akan tetapi, varietas Sintanur lebih tahan terhadap yellowing dengan nilai BWD pada dua musim tanam paling tinggi dibandingkan varietas lainnya. Sintanur memiliki keparahan penyakit Bercak Daun Cercospora paling rendah dibandingkan varietas lainnya. Keparahan penyakit umumnya meningkat seiring dengan bertambahnya umur padi, sedangkan kepadatan populasi hama dan musuh alami berfluktuasi. Kepadatan hama cukup tinggi pada plot kontrol, sedangkan kepadatan musuh alami cukup tinggi pada plot aplikasi ekstrak daun Mindi, Mahoni, dan Sirsak.
\end{abstract}

Kata kunci: hama, musuh alami, penyakit, pertanian organik

\begin{abstract}
Organic rice cultivation intents to minimize the use of inorganic fertilizers and chemical pesticides, but in fact not apart from the disruption of pests and diseases. The study aimed to determine the pests, diseases, and natural enemies on organic rice cultivation. The research was conducted at Screen Field of ICRR at WS 2015/2016 and DS 2016, using Split Plot research design with three replications. The main plot was varieties of: 1). Inpari 25, 2). Inpari 33, and 3). Sintanur. The sub-plot was application of leaf extract of: 1). Mindi, 2). Soursop, 3).
\end{abstract}


Mahogany, and 4). Control. Applications were performed on 4, 6, 8, and 10 weeks after planting (WAP). Observations of pests, diseases, and natural enemies on $5,7,9$, and 11 WAP as many as 20 clumps/plots. The results showed that varieties and leaf extract applications significantly affected on severity of stem rot disease at 5 and 7 WAP in WS 2015/2016. In the rainy season found Yellowing on Inpari 25 and Inpari 33 varieties. However, Sintanur was more resistant to Yellowing with LCC value on two growing seasons was highest compared to the other varieties. Sintanur had the lowest Cercospora Leaf Spot disease severity compared to the other varieties. The severity of disease generally increased with the age of rice increase, while the pest population density and natural enemies were fluctuate. The density of the pest was quite high in the control plot, while the natural enemy density was high enough in the application plots of Mindi, Mahogany, and Soursop extracts.

Key words: diseases, natural enemies, organic farming, pests

\section{PENDAHULUAN}

Pertanian organik semakin mendapat perhatian dari berbagai kalangan masyarakat. Semakin banyak yang menyadari arti kesehatan baik untuk manusia maupun lingkungan selain kecukupan pangan saat ini. Produk pertanian organik diyakini dapat menjamin kesehatan manusia dan lingkungan karena dihasilkan melalui proses produksi yang berwawasan lingkungan (Widiarta, 2011).

Praktek budidaya padi organik memiliki beberapa kelebihan diantaranya keseimbangan tanah dapat terjaga karena tidak menggunakan pupuk anorganik dan pestisida kimia, namun menggunakan pupuk kandang, pupuk hijau dan sisa tanaman. Kelebihan lainnya yaitu masyarakat dapat mengkonsumsi produk pertanian yang bebas residu pestisida dan meningkatkan kesejahteraan petani dengan nilai jual produk yang lebih tinggi. Budidaya padi organik pun memiliki beberapa kekurangan diantaranya membutuhkan pengelolaan lahan yang cukup rumit, pada awal penerapannya banyak dijumpai permasalahan sehingga petani putus asa, membutuhkan waktu yang cukup lama untuk mendapatkan hasil yang maksimal, dan meningkatkan biaya tenaga kerja apabila diterapkan dalam skala luas (Roidah, 2013).

Salah satu masalah dalam budidaya padi organik adalah serangan Organisme Pengganggu Tanaman (OPT) yang terdiri dari hama, penyakit tanaman, dan gulma. Namun kendala OPT tersebut dapat diminimalisir dengan penerapan budidaya organik secara komprehensif dan berkelanjutan. Budidaya organik mampu menekan proporsi serangga hama dan mempertahankan proporsi musuh alami dan serangga netral tetap tinggi mulai dari fase vegetatif awal hingga masa bera. Cara budidaya padi organik merupakan habitat yang baik bagi musuh alami (predator dan parasitoid), meskipun kelimpahan populasinya lebih rendah dibandingkan dengan cara budidaya Pengelolaan Tanaman Terpadu (Widiarta et al., 2006).

Pengendalian OPT dalam budidaya padi organik dapat dilakukan dengan menerapkan konsep Pengendalian Hama Terpadu (PHT). Musuh alami merupakan salah satu dari komponen PHT. Musuh alami yang dapat diterapkan di lapangan antara lain parasitoid, predator, patogen untuk mengendalikan hama. Jamur antagonis, Plant Growth Promoting Rhizobacteria, 
pengimbasan ketahanan, proteksi silang, tanaman campuran untuk mengendalikan penyakit (Laba dan Willis, 2014). Selain pemanfaatan musuh alami untuk pengendalian OPT, teknik pengendalian yang tidak kalah penting diantaranya penanaman varietas tahan dan perbaikan pola tanam (Gribaldi, 2009).

Hal yang tidak kalah penting dalam praktek budidaya padi organik adalah peranan bahan organik dalam meningkatkan kesuburan tanah yang akan menentukan produktivitas tanah. Peranan bahan organik tidak hanya berperan dalam penyediaan hara tanaman saja, namun yang jauh lebih penting dapat memperbaiki struktur tanah, mempermudah pengolahan tanah, meningkatkan aktivitas mikroba tanah yang berdampak positif bagi pertumbuhan tanaman (Atmojo, 2003). Bahan organik yang diperbolehkan dalam sistem pertanian organik diantaranya pupuk hayati, kompos sisa tanaman, pupuk kandang, pembenah tanah, dan zat pengatur tumbuh (Djazuli, 2014).

Fungsi bahan organik diantaranya menjadi sumber makanan bagi mikroorganisme tanah sehingga perkembangannya menjadi lebih cepat (Hadisuwito, 2008). Mikroorganisme atau mikroba yang hidup pada pertanian organik dapat memperbaiki kondisi lingkungan fisik, kimia, dan biologi tanah serta menekan pertumbuhan hama dan keparahan penyakit (Nasahi, 2010). Kelimpahan hama secara langsung berkaitan dengan kelimpahan musuh alami di pertanaman padi.

Teknologi pengendalian OPT saat ini masih sangat terbatas, apalagi teknologi pengendalian yang berbasis organik. Menurut Gribaldi (2009), perlu dilakukan usaha untuk menghasilkan teknologi pengendalian OPT yang berwawasan lingkungan. Pengendalian bukan bermaksud untuk menghilangkan OPT, namun untuk mengendalikan kelimpahan populasi hama dan keparahan penyakit yang dapat merusak dan merugikan secara ekonomi. Penelitian ini bertujuan untuk mengetahui keragaan hama, penyakit, dan musuh alami pada budidaya padi organik.

\section{BAHAN DAN METODE}

\section{Tempat dan Desain penelitian}

Penelitian dilaksanakan di Screen Field Balai Besar Penelitian Tanaman Padi Sukamandi pada musim hujan (MH) 2015/2016 dan musim kemarau (MK) 2016. Rancangan penelitian berupa Split Plot dengan tiga ulangan. Petak utama adalah: 1). Varietas Inpari 25, 2). Varietas Inpari 33, dan 3). Varietas Sintanur. Anak petak adalah aplikasi ekstrak daun: 1). Mindi, 2). Sirsak, 3). Mahoni, dan 4). Kontrol. Ukuran plot 14 $\mathrm{m}^{2}$ dengan jarak tanam $25 \mathrm{~cm} \times 25 \mathrm{~cm}$. Umur bibit yang digunakan \pm 21 hari setelah sebar. Semua plot perlakuan tidak diberikan pupuk dan pestisida kimia. Pupuk organik berupa kompos kotoran sapi hanya diberikan satu kali pada saat pengolahan tanah sebanyak $200 \mathrm{~kg}$ per $2000 \mathrm{~m}^{2}$. Penggunaan tanaman Mindi, Sirsak, dan Mahoni karena banyak ditemukan di lingkungan sekitar.

\section{Persiapan dan Aplikasi Ekstrak Tanaman}

Persiapan aplikasi yaitu daun tanaman Mindi, Sirsak, dan Mahoni ditimbang masing-masing $300 \mathrm{~g}$. Masing-masing daun dipotong kecil-kecil $\pm 1 \mathrm{~cm}$, kemudian diblender sampai halus. Ekstrak daun disaring dengan kain halus dan ditambahkan air sebanyak $3 \mathrm{~L}$. Masing-masing ekstrak disemprotkan pada plot perlakuan. Aplikasi 
ekstrak daun Mindi, Sirsak, dan Mahoni dilakukan pada umur padi 4, 6, 8, dan 10 Minggu Setelah Tanam (MST).

Pengamatan Hama, Penyakit, dan Musuh Alami

Pengamatan terhadap hama, penyakit, dan musuh alami dilakukan pada umur padi 5, 7, 9, dan 11 MST pada 20 rumpun sampel masing-masing plot. Pengamatan hama dan musuh alami dengan cara menghitung kepadatan populasi pada masing-masing rumpun sampel. Pengamatan penyakit padi dilakukan dengan cara skoring keparahan gejala penyakit berdasarkan Standard Evaluation System untuk padi (IRRI, 2014). Skoring gejala kemudian dikonversi ke dalam rumus keparahan penyakit yaitu:

$$
K P=\sum \frac{(n i . V i)}{Z . n} \times 100 \%
$$

Keterangan:

$\mathrm{KP}=$ Keparahan penyakit (\%)

ni = Jumlah sampel dengan nilai skor keparahan tertentu

$\mathrm{i}=$ Skor keparahan $(0,1,3,5,7$, dan 9)

$\mathrm{V}=$ Nilai skala dari sampel ke-i

$\mathrm{N}$ = Jumlah sampel yang diamati

Z = Skor keparahan tertinggi

Pengamatan Bagan Warna Daun (BWD) untuk mengetahui kecukupan tanaman padi terhadap unsur $\mathrm{N}$ dilakukan pada 7 dan 9 MST. Selain itu, dilakukan pengamatan apabila ada gejala Yellowing akibat kekurangan unsur $\mathrm{N}$.

\section{Analisis Statistik}

Data pengamatan yang diperoleh dianalisis dengan analisis sidik ragam (ANOVA). Perbedaan antar perlakuan dievaluasi dengan uji lanjut Duncan dengan tingkat beda nyata 5\% (Gomez and Gomez, 1995).

\section{HASIL DAN PEMBAHASAN}

\section{Keragaan Penyakit dan Musuh Alami pada MH 2015/2016}

Hasil analisis sidik ragam pada $\mathrm{MH}$ 2015/2016 dan MK 2016 menunjukkan tidak terjadi interaksi antara varietas (petak utama) dengan aplikasi ekstrak daun (anak petak) terhadap kepadatan populasi hama, keparahan penyakit, dan musuh alami pada tanaman padi. Keberadaan hama padi tidak ditemukan pada MH 2015/2016.

\section{Penyakit Padi}

Hasil penelitian menunjukkan bahwa penyakit busuk batang yang disebabkan oleh cendawan Helminthosporium sigmoideum mulai terlihat pada umur padi 5 MST. Keparahan penyakit busuk batang meningkat seiring dengan bertambahnya umur tanaman padi. Keparahan busuk batang terendah ditemukan pada varietas Sintanur dan menunjukkan berbeda nyata dengan varietas lainnya pada 5 hingga 9 MST (Tabel 1).

Aplikasi ekstrak Mindi dan Sirsak menunjukkan keparahan busuk batang relatif lebih rendah pada umur padi 5 MST dan berbeda nyata terhadap kontrol. Pada umur padi 7 MST, keparahan penyakit relatif lebih rendah dijumpai pada plot yang diberi perlakuan ekstrak daun Sirsak. Pada umur padi 9 dan 11 MST, keparahan penyakit relatif lebih rendah dijumpai pada plot yang diberi perlakuan ekstrak daun Mindi. Antar perlakuan aplikasi ekstrak daun menunjukkan tidak berbeda nyata pada umur padi 7 hingga 11 MST (Tabel 1). 
Tabel 1. Keparahan penyakit busuk batang padi pada budidaya padi organik, Sukamandi MH 2015/2016.

\begin{tabular}{|c|c|c|c|c|}
\hline \multirow{2}{*}{ Perlakuan } & \multicolumn{4}{|c|}{ Keparahan Penyakit \% } \\
\hline & 5 MST & $7 \mathrm{MST}$ & $9 \mathrm{MST}$ & $11 \mathrm{MST}$ \\
\hline & \multicolumn{4}{|c|}{--\%-- } \\
\hline \multicolumn{5}{|l|}{ Varietas } \\
\hline Inpari 25 & $7,92 a b$ & $9,26 \mathrm{a}$ & 10,56 a & $15,11 \mathrm{a}$ \\
\hline Inpari 33 & 8,15 a & 9,35 a & $10,97 \mathrm{a}$ & $10,97 \mathrm{a}$ \\
\hline Sintanur & $6,39 \mathrm{~b}$ & $6,95 \mathrm{~b}$ & $7,50 \mathrm{~b}$ & $9,31 \mathrm{a}$ \\
\hline \multicolumn{5}{|l|}{ Aplikasi } \\
\hline Mindi & $6,23 \mathrm{~b}$ & $7,96 \mathrm{a}$ & $9,07 a$ & $9,07 a$ \\
\hline Sirsak & $6,23 \mathrm{~b}$ & $7,72 \mathrm{a}$ & $9,75 \mathrm{a}$ & $11,76 \mathrm{a}$ \\
\hline Mahoni & $8,33 a b$ & 8,46 a & $10,00 \mathrm{a}$ & $12,28 \mathrm{a}$ \\
\hline Kontrol & 9,13 a & $9,94 \mathrm{a}$ & $9,88 \mathrm{a}$ & $14,06 \mathrm{a}$ \\
\hline
\end{tabular}

Keterangan : Huruf yang sama pada satu kolom menunjukkan data tidak berbeda nyata berdasarkan Duncan 5\%

Pada umur padi 5 MST ditemukan gejala yellowing yaitu daun padi menunjukkan gejala menguning akibat lahan sawah tidak diberikan pupuk $\mathrm{N}$ (urea). Namun gejala ini menghilang saat umur padi 7 MST dan seterusnya. Sintanur merupakan varietas yang sangat tahan terhadap gejala yellowing, warna daun tetap hijau, dan tidak menunjukkan gejala kekurangan unsur N. Insiden yellowing pada varietas Sintanur menunjukkan perbedaan yang nyata dengan kedua varietas lainnya. Gejala yellowing dijumpai cukup rendah pada plot yang diaplikasi dengan ekstrak daun sirsak, namun tidak berbeda nyata dengan aplikasi ekstrak daun lainnya (Tabel 2).

Tabel 2. Keparahan Gejala Yellowing pada Budidaya Padi Organik, Sukamandi MH 2015/2016.

\begin{tabular}{|c|c|c|c|c|}
\hline \multirow{2}{*}{ Perlakuan } & \multicolumn{4}{|c|}{ Gejala Yellowing } \\
\hline & $5 \mathrm{MST}$ & $7 \mathrm{MST}$ & $9 \mathrm{MST}$ & $11 \mathrm{MST}$ \\
\hline & \multicolumn{4}{|c|}{--\%-- } \\
\hline \multicolumn{5}{|l|}{ Varietas } \\
\hline Inpari 25 & $23,26 \mathrm{a}$ & - & - & - \\
\hline Inpari 33 & 27,15 a & - & - & - \\
\hline Sintanur & $0,00 \mathrm{~b}$ & - & - & - \\
\hline \multicolumn{5}{|l|}{ Aplikasi } \\
\hline Mindi & $15,00 \mathrm{a}$ & - & - & - \\
\hline Sirsak & $14,72 \mathrm{a}$ & - & - & - \\
\hline Mahoni & $18,70 \mathrm{a}$ & - & - & - \\
\hline Kontrol & $18,80 \mathrm{a}$ & - & - & - \\
\hline
\end{tabular}

Keterangan : Huruf yang sama pada satu kolom menunjukkan data tidak berbeda nyata berdasarkan Duncan 5\%

Penyakit hawar pelepah mulai ditemukan pada umur padi 9 MST. Keparahan penyakit hawar pelepah relatif lebih rendah pada umur padi 9 hingga 11
MST ditemukan pada varietas Sintanur. Diantara aplikasi ekstrak daun, keparahan hawar pelepah relatif lebih rendah pada 9 hingga 11 MST pada plot yang diaplikasi 
ekstrak daun Mindi (Tabel 3). Baik varietas

penyakit hawar pelepah selama $\mathrm{MH}$ maupun aplikasi ekstrak daun menunjukkan 2015/2016.

tidak berbeda nyata terhadap keparahan

Tabel 3. Keparahan Penyakit Hawar Pelepah Padi pada Budidaya Padi Organik, Sukamandi MH 2015/2016

\begin{tabular}{lcccc}
\hline \multirow{2}{*}{ Perlakuan } & \multicolumn{4}{c}{ Keparahan Penyakit } \\
\cline { 2 - 5 } & $5 \mathrm{MST}$ & $7 \mathrm{MST}$ & $9 \mathrm{MST}$ & $11 \mathrm{MST}$ \\
\hline Varietas & \multicolumn{5}{c}{- -- } \\
Inpari 25 & - & - & $1,81 \mathrm{a}$ & $5,74 \mathrm{a}$ \\
Inpari 33 & - & - & $2,08 \mathrm{a}$ & $4,91 \mathrm{a}$ \\
Sintanur & - & - & $1,34 \mathrm{a}$ & $3,29 \mathrm{a}$ \\
Aplikasi & - & - & $1,54 \mathrm{a}$ & $3,83 \mathrm{a}$ \\
Mindi & - & - & $1,98 \mathrm{a}$ & $4,20 \mathrm{a}$ \\
Sirsak & - & - & $1,73 \mathrm{a}$ & $5,87 \mathrm{a}$ \\
Mahoni & - & - & $1,73 \mathrm{a}$ & $4,69 \mathrm{a}$ \\
Kontrol & - & &
\end{tabular}

Keterangan : Huruf yang sama pada satu kolom menunjukkan data tidak berbeda nyata berdasarkan Duncan 5\%

Penyakit Cercospora Leaf Spot (CLS) mulai ditemukan pada umur padi 9 MST. Varietas unggul baru seperti Inpari 25 dan Inpari 33 menunjukkan keparahan penyakit CLS cukup tinggi terutama pada umur padi 11 MST. Namun varietas Sintanur menunjukkan keparahan penyakit relatif lebih rendah pada umur padi 9 hingga 11 MST dan berbeda nyata terhadap varietas Inpari 33, namun tidak berbeda nyata terhadap varietas Inpari 25. Aplikasi ekstrak daun Mindi menunjukkan keparahan penyakit relatif lebih rendah dibandingkan aplikasi ekstrak daun lainnya, namun tidak berbeda nyata pada semua perlakuan aplikasi (Tabel 4). Menurut Suprihanto et al. (2009), bercak daun Cercospora menunjukkan paling rentan pada dosis pemupukan nitrogen dengan dosis yang paling rendah.

Tabel 4. Keparahan Penyakit Cercospora Leaf Spot pada Budidaya Padi Organik, Sukamandi MH 2015/2016

\begin{tabular}{|c|c|c|c|c|}
\hline \multirow{2}{*}{ Perlakuan } & \multicolumn{4}{|c|}{ Keparahan Penyakit } \\
\hline & $5 \mathrm{MST}$ & $7 \mathrm{MST}$ & $9 \mathrm{MST}$ & 11 MST \\
\hline & \multicolumn{4}{|c|}{--\%-- } \\
\hline \multicolumn{5}{|l|}{ Varietas } \\
\hline Inpari 25 & - & - & $10,88 a$ & $31,30 a b$ \\
\hline Inpari 33 & - & - & $11,02 \mathrm{a}$ & $45,23 a$ \\
\hline Sintanur & - & - & $0,00 \mathrm{~b}$ & $11,25 \mathrm{~b}$ \\
\hline \multicolumn{5}{|l|}{ Aplikasi } \\
\hline Mindi & - & - & $7,10 \mathrm{a}$ & $27,53 \mathrm{a}$ \\
\hline Sirsak & - & - & $7,35 \mathrm{a}$ & $29,75 \mathrm{a}$ \\
\hline Mahoni & - & - & $7,41 \mathrm{a}$ & $28,64 \mathrm{a}$ \\
\hline Kontrol & - & - & $7,35 \mathrm{a}$ & $31,11 \mathrm{a}$ \\
\hline
\end{tabular}

Keterangan : Huruf yang sama pada satu kolom menunjukkan data tidak berbeda nyata berdasarkan Duncan $5 \%$ 


\section{Musuh Alami pada Padi}

Kepadatan populasi laba-laba relatif lebih tinggi pada umur padi 5 hingga 9 MST ditemukan pada varietas Sintanur, sedangkan pada 11 MST ditemukan pada varietas Inpari 25 . Populasi laba-laba dengan kepadatan relatif lebih tinggi dijumpai pada plot yang diaplikasi dengan ekstrak daun Mahoni pada umur padi 5 hingga 7 MST, sedangkan pada 9 hingga 11 MST dijumpai pada plot yang diaplikasi dengan ekstrak daun Sirsak. Secara umum trends populasi laba-laba pada $\mathrm{MH}$ 2015/2016 cukup tinggi pada umur padi 5 MST dan populasi puncaknya pada 7 MST, namun pada 9 hingga 11 MST populasi labalaba cenderung menurun (Tabel 5). Baik varietas maupun aplikasi ekstrak daun menunjukkan tidak berbeda nyata terhadap kepadatan populasi laba-laba pada semua waktu pengamatan.

Tabel 5. Kepadatan Populasi Laba-laba pada Budidaya Padi Organik, Sukamandi MH $2015 / 2016$.

\begin{tabular}{lcccc}
\hline \multirow{2}{*}{ Perlakuan } & \multicolumn{4}{c}{ Kepadatan Populasi } \\
\cline { 2 - 5 } Varietas & $5 \mathrm{MST}$ & $7 \mathrm{MST}$ & $9 \mathrm{MST}$ & $11 \mathrm{MST}$ \\
$\quad$ Inpari 25 & \multicolumn{3}{c}{--ekor-- } \\
$\quad$ Inpari 33 & $31,58 \mathrm{a}$ & $33,50 \mathrm{a}$ & $32,00 \mathrm{a}$ & $25,00 \mathrm{a}$ \\
$\quad$ Sintanur & $35,17 \mathrm{a}$ & $35,75 \mathrm{a}$ & $32,75 \mathrm{a}$ & $20,92 \mathrm{a}$ \\
Aplikasi & $36,42 \mathrm{a}$ & $37,25 \mathrm{a}$ & $32,92 \mathrm{a}$ & $23,58 \mathrm{a}$ \\
$\quad$ Mindi & $33,78 \mathrm{a}$ & $35,33 \mathrm{a}$ & $32,56 \mathrm{a}$ & $22,67 \mathrm{a}$ \\
Sirsak & $33,44 \mathrm{a}$ & $36,11 \mathrm{a}$ & $33,11 \mathrm{a}$ & $23,67 \mathrm{a}$ \\
$\quad$ Mahoni & $36,56 \mathrm{a}$ & $36,67 \mathrm{a}$ & $32,00 \mathrm{a}$ & $23,00 \mathrm{a}$ \\
$\quad$ Kontrol & $33,78 \mathrm{a}$ & $33,89 \mathrm{a}$ & $32,56 \mathrm{a}$ & $23,33 \mathrm{a}$ \\
\hline
\end{tabular}

Keterangan : Huruf yang sama pada satu kolom menunjukkan data tidak berbeda nyata berdasarkan Duncan 5\%

Tabel 6. Kepadatan Populasi Phaederus sp. pada Budidaya Padi Organik, Sukamandi MH 2015/2016

\begin{tabular}{lcccc}
\hline \multirow{2}{*}{ Perlakuan } & \multicolumn{4}{c}{ Kepadatan Populasi } \\
\cline { 2 - 5 } Varietas & $5 \mathrm{MST}$ & 7 MST & $9 \mathrm{MST}$ & $11 \mathrm{MST}$ \\
$\quad$ Inpari 25 & $2,08 \mathrm{a}$ & $1,75 \mathrm{a}$ & $2,17 \mathrm{ab}$ & $3,33 \mathrm{a}$ \\
$\quad$ Inpari 33 & $3,58 \mathrm{a}$ & $2,42 \mathrm{a}$ & $1,92 \mathrm{~b}$ & $1,92 \mathrm{a}$ \\
$\quad$ Sintanur & $2,83 \mathrm{a}$ & $3,08 \mathrm{a}$ & $3,33 \mathrm{a}$ & $2,17 \mathrm{a}$ \\
Aplikasi & & & & \\
$\quad$ Mindi & $2,22 \mathrm{a}$ & $2,22 \mathrm{a}$ & $1,89 \mathrm{a}$ & $2,78 \mathrm{a}$ \\
Sirsak & $3,78 \mathrm{a}$ & $2,89 \mathrm{a}$ & $2,56 \mathrm{a}$ & $2,78 \mathrm{a}$ \\
Mahoni & $3,56 \mathrm{a}$ & $1,89 \mathrm{a}$ & $2,78 \mathrm{a}$ & $2,00 \mathrm{a}$ \\
$\quad$ Kontrol & $1,78 \mathrm{a}$ & $2,67 \mathrm{a}$ & $2,67 \mathrm{a}$ & $2,33 \mathrm{a}$ \\
\hline
\end{tabular}

Keterangan : Huruf yang sama pada satu kolom menunjukkan data tidak berbeda nyata berdasarkan Duncan 5\% 
Kepadatan populasi Phaederus sp. relatif lebih tinggi pada umur padi 5 MST teridentifikasi pada varietas Inpari 33, sedangkan pada 7 hingga 9 MST dijumpai pada varietas Sintanur (Tabel 6).

Pengamatan terakhir yaitu pada umur padi 11 MST menunjukkan kepadatan populasi Phaederus sp. relatif lebih tinggi ditemukan pada varietas Inpari 25. Populasi Phaederus sp. dengan kepadatan relatif lebih tinggi dijumpai pada plot yang diaplikasi dengan ekstrak daun sirsak pada umur padi 5 hingga 7 MST, sedangkan pada 9 MST dijumpai pada plot yang diaplikasi dengan ekstrak daun Mahoni. Kepadatan populasi Phaederus sp. relatif lebih tinggi pada umur padi 11 MST dijumpai pada plot yang diaplikasi dengan ekstrak daun mindi atau sirsak (Tabel 6). Baik varietas maupun aplikasi ekstrak daun menunjukkan tidak berbeda nyata terhadap kepadatan populasi Phaederus sp. pada semua waktu pengamatan.

Keragaan Hama, Penyakit, dan Musuh Alami pada MK 2016

Hama Padi

Kepadatan populasi wereng cokelat relatif lebih tinggi pada umur padi 5 MST teridentifikasi pada varietas Inpari 33, sedangkan pada 7 hingga 9 MST dijumpai pada varietas Inpari 25. Pengamatan terakhir yaitu umur padi 11 MST menunjukkan kepadatan populasi wereng cokelat relatif lebih tinggi ditemukan pada varietas Sintanur. Perlakuan varietas tidak berbeda nyata terhadap kepadatan populasi wereng cokelat pada semua waktu pengamatan (Tabel 7).

Populasi wereng cokelat dengan kepadatan relatif lebih tinggi dijumpai pada plot yang diaplikasi dengan ekstrak daun mahoni pada umur padi 5 MST dan berbeda nyata dengan kepadatan populasi wereng coklat pada plot yang diaplikasi dengan ekstrak daun mindi. Kepadatan populasi wereng cokelat relatif lebih tinggi pada umur padi 7 MST dijumpai pada plot yang diaplikasi dengan ekstrak daun mindi atau sirsak. Kepadatan populasi wereng cokelat relatif lebih tinggi pada umur padi 9 hingga 11 MST dijumpai pada plot yang diaplikasi dengan ekstrak daun mahoni (Tabel 7). Kepadatan populasi wereng cokelat tidak berbeda nyata pada umur padi 7 hingga 11 MST baik pada perlakuan varietas maupun aplikasi ekstrak daun.

Tabel 7. Kepadatan Populasi Wereng Cokelat pada Budidaya Padi Organik, Sukamandi MK 2016.

\begin{tabular}{lcccc}
\hline \multirow{2}{*}{ Perlakuan } & \multicolumn{5}{c}{ Kepadatan Populasi } \\
\cline { 2 - 5 } Varietas & $5 \mathrm{MST}$ & \multicolumn{3}{c}{--ekor-- } \\
$\quad$ Inpari 25 & $1,42 \mathrm{a}$ & $1,67 \mathrm{a}$ & $1,55 \mathrm{a}$ & $6,92 \mathrm{a}$ \\
$\quad$ Inpari 33 & $1,83 \mathrm{a}$ & $1,17 \mathrm{a}$ & $1,50 \mathrm{a}$ & $6,33 \mathrm{a}$ \\
$\quad$ Sintanur & $0,83 \mathrm{a}$ & $0,75 \mathrm{a}$ & $0,79 \mathrm{a}$ & $7,42 \mathrm{a}$ \\
Aplikasi & & & & \\
$\quad$ Mindi & $0,78 \mathrm{~b}$ & $1,22 \mathrm{a}$ & $1,00 \mathrm{a}$ & $6,00 \mathrm{a}$ \\
Sirsak & $1,33 \mathrm{ab}$ & $1,22 \mathrm{a}$ & $1,28 \mathrm{a}$ & $6,56 \mathrm{a}$ \\
$\quad$ Mahoni & $2,22 \mathrm{a}$ & $0,78 \mathrm{a}$ & $1,50 \mathrm{a}$ & $7,89 \mathrm{a}$ \\
$\quad$ Kontrol & $1,11 \mathrm{ab}$ & $1,56 \mathrm{a}$ & $1,34 \mathrm{a}$ & $7,11 \mathrm{a}$ \\
\hline
\end{tabular}


Keterangan : Huruf yang sama pada satu kolom menunjukkan data tidak berbeda nyata berdasarkan Duncan 5\%

Sukamandi merupakan daerah hot spot wereng cokelat karena hampir tiap musim tanam padi ditemukan kerusakan akibat serangan wereng cokelat. Menurut Baehaki (2011), daerah hot spot wereng cokelat adalah daerah dimana selalu terjadi ledakan wereng cokelat tiap tahunnya. Besarnya ledakan tergantung dari musim dan pendukung penyebab ledakan. Daerah hot spot wereng cokelat sebenarnya tidak banyak hanya 7 titik provinsi yaitu Banten (Pandeglang); Jawa Barat (Karawang dan Subang); Jawa Tengah (Klaten); Jawa Timur (Jember dan Banyuwangi); dan Sumatera Utara (Simalungun).

Populasi kepinding tanah hanya ditemukan pada umur padi 5 MST engan kepadatan relatif lebih tinggi dijumpai pada varietas Sintanur juga pada plot perlakuan kontrol (Tabel 8). Keberadaan kepinding tanah hanya dijumpai pada umur padi 5 MST karena bertepatan dengan bulan purnama sehingga banyak ditemukan di pertanaman padi. Namun apabila telah melewati bulan purnama, populasi kepinding tanah secara perlahan menghilang dari pertanaman padi. Populasi kepinding tanah tidak berbeda nyata pada semua perlakuan baik varietas maupun aplikasi ekstrak daun karena hama tersebut menyebar secara merata pada semua petak percobaan.

Menurut Ismawati (2012), imago kepinding tanah mulai ditemukan pada pertanaman padi setelah $3 \mathrm{MST}$, fase telur setelah $4 \mathrm{MST}$, nimfa kecil setelah 5 MST, dan nimfa besar setelah 6 MST. Kepadatan populasi kepinding tanah umumnya meningkat setelah tanaman memasuki fase generatif pada umur 9 MST dan perkembangan populasi kepinding tanah berfluktuasi sampai menjelang panen.

Tabel 8. Kepadatan Populasi Kepinding Tanah pada Budidaya Padi Organik, Sukamandi MK 2016.

\begin{tabular}{|c|c|c|c|c|}
\hline \multirow{2}{*}{ Perlakuan } & \multicolumn{4}{|c|}{ Kepadatan Populasi } \\
\hline & $5 \mathrm{MST}$ & $7 \mathrm{MST}$ & $9 \mathrm{MST}$ & $11 \mathrm{MST}$ \\
\hline & \multicolumn{4}{|c|}{--ekor-- } \\
\hline \multicolumn{5}{|l|}{ Varietas } \\
\hline Inpari 25 & $0,83 \mathrm{a}$ & - & - & - \\
\hline Inpari 33 & $0,75 \mathrm{a}$ & - & - & - \\
\hline Sintanur & $1,83 \mathrm{a}$ & - & - & - \\
\hline \multicolumn{5}{|l|}{ Aplikasi } \\
\hline Mindi & 0,67 a & - & - & - \\
\hline Sirsak & 0,78 a & - & - & - \\
\hline Mahoni & $1,44 \mathrm{a}$ & - & - & - \\
\hline Kontrol & $1,67 \mathrm{a}$ & - & - & - \\
\hline
\end{tabular}

Keterangan : Huruf yang sama pada satu kolom menunjukkan data tidak berbeda nyata berdasarkan Duncan $5 \%$

Populasi hama putih palsu kan pada umur padi 5 MST. Kepadatan (Cnaphalocrosis medinalis) hanya ditemu- populasi hama putih palsu relatif lebih 
tinggi dijumpai pada varietas Inpari 25 juga pada plot perlakuan kontrol. Perlakuan varietas maupun aplikasi ekstrak daun tidak berbeda nyata terhadap kepadatan populasi hama putih palsu (Tabel 9). Hal ini sejalan dengan hasil penelitian Tangkilisan et al.
(2013), bahwa persentase serangan dan populasi hama putih palsu relatif lebih tinggi ditemukan pada tanaman padi berumur $6 \mathrm{MST}$, sedangkan pada tanaman berumur 1 dan 2 MST tidak ditemukan serangan.

Tabel 9. Kepadatan Populasi Hama Putih Palsu pada Budidaya Padi Organik, Sukamandi MK 2016

\begin{tabular}{lcccc}
\hline \multirow{2}{*}{ Perlakuan } & \multicolumn{4}{c}{ Kepadatan Populasi } \\
\cline { 2 - 5 } & $5 \mathrm{MST}$ & $7 \mathrm{MST}$ & $9 \mathrm{MST}$ & $11 \mathrm{MST}$ \\
\hline Varietas & & \multicolumn{4}{c}{--ekor-- } \\
$\quad$ Inpari 25 & $22,58 \mathrm{a}$ & - & - & - \\
Inpari 33 & $19,58 \mathrm{a}$ & - & - & - \\
Sintanur & $22,42 \mathrm{a}$ & - & - & - \\
Aplikasi & $18,89 \mathrm{a}$ & - & - & - \\
Mindi & $23,00 \mathrm{a}$ & - & - & - \\
Sirsak & $20,56 \mathrm{a}$ & - & - & - \\
Mahoni & $23,67 \mathrm{a}$ & - & - & - \\
Kontrol & & & - & \\
\hline
\end{tabular}

Keterangan : Huruf yang sama pada satu kolom menunjukkan data tidak berbeda nyata berdasarkan Duncan 5\%

Populasi wereng punggung putih hanya ditemukan pada umur padi 5 dan 7 MST. Hal ini berkaitan persaingan ruang antara wereng punggung putih dengan wereng cokelat. Kepadatan populasi wereng punggung putih relatif lebih tinggi dijumpai pada varietas Sintanur, namun tidak berbeda nyata antar perlakuan varietas. Kepadatan populasi wereng punggung putih relatif lebih rendah ditemukan pada plot yang diaplikasi dengan ekstrak daun Mahoni dan berbeda nyata dibandingkan dengan aplikasi ekstrak daun Sirsak dan kontrol pada umur 7 MST(Tabel 10).

Tabel 10. Kepadatan Populasi Wereng Punggung Putih pada Budidaya Padi Organik, Sukamandi MK 2016.

\begin{tabular}{lcccc}
\hline \multirow{2}{*}{ Perlakuan } & \multicolumn{5}{c}{ Kepadatan Populasi } \\
\cline { 2 - 5 } & $5 \mathrm{MST}$ & $7 \mathrm{MST}$ & $9 \mathrm{MST}$ & $11 \mathrm{MST}$ \\
\hline Varietas & & \multicolumn{3}{c}{--ekor-- } \\
$\quad$ Inpari 25 & $0,58 \mathrm{a}$ & $7,50 \mathrm{a}$ & - & - \\
Inpari 33 & $0,75 \mathrm{a}$ & $8,75 \mathrm{a}$ & - & - \\
Sintanur & $1,50 \mathrm{a}$ & $9,58 \mathrm{a}$ & - & - \\
Aplikasi & & & & - \\
Mindi & $0,56 \mathrm{a}$ & $8,89 \mathrm{ab}$ & - & - \\
Sirsak & $1,22 \mathrm{a}$ & $8,44 \mathrm{a}$ & - & - \\
Mahoni & $0,56 \mathrm{a}$ & $6,89 \mathrm{~b}$ & - & - \\
Kontrol & $1,44 \mathrm{a}$ & $10,22 \mathrm{a}$ & - & - \\
\hline
\end{tabular}

Keterangan : Huruf yang sama pada satu kolom menunjukkan data tidak berbeda nyata berdasarkan Duncan 5\% 


\section{Penyakit Padi}

Keparahan penyakit busuk batang meningkat seiring dengan bertambahnya umur tanaman padi baik pada $\mathrm{MH}$ 2015/2016 maupun MK 2016. Keparahan busuk batang relatif lebih rendah ditemukan pada varietas Sintanur pada umur padi 5 hingga 9 MST, sedangkan pada 11 MST ditemukan pada varietas Inpari 33. Keparahan busuk batang tidak berbeda nyata pada perlakuan varietas di semua waktu pengamatan. Aplikasi ekstrak daun Mindi atau Sirsak menunjukkan keparahan busuk batang relatif lebih rendah pada umur padi 5 MST. Keparahan penyakit relatif lebih rendah dijumpai pada plot perlakuan yang diaplikasi oleh ekstrak daun Sirsak pada umur padi 7 dan 9 MST. Aplikasi ekstrak daun menunjukkan tidak berbeda nyata terhadap keparahan busuk batang pada pada umur padi 5 hingga 9 MST. Keparahan penyakit relatif lebih rendah pada 11 MST dijumpai pada plot yang diaplikasi oleh ekstrak daun Mindi dan berbeda nyata dengan perlakuan kontrol (Tabel 11).

Tabel 11. Keparahan Penyakit Busuk Batang Padi pada Budidaya Padi Organik, Sukamandi MK 2016.

\begin{tabular}{lcccc}
\hline \multirow{2}{*}{ Perlakuan } & \multicolumn{4}{c}{ Keparahan Penyakit } \\
\cline { 2 - 5 } & $5 \mathrm{MST}$ & $7 \mathrm{MST}$ & $9 \mathrm{MST}$ & $11 \mathrm{MST}$ \\
\hline Varietas & & & $--\%--$ \\
$\quad$ Inpari 25 & $9,35 \mathrm{a}$ & $10,09 \mathrm{a}$ & $15,82 \mathrm{a}$ & $24,14 \mathrm{a}$ \\
$\quad$ Inpari 33 & $9,81 \mathrm{a}$ & $9,91 \mathrm{a}$ & $14,90 \mathrm{a}$ & $23,77 \mathrm{a}$ \\
$\quad$ Sintanur & $8,70 \mathrm{a}$ & $9,17 \mathrm{a}$ & $11,67 \mathrm{a}$ & $24,14 \mathrm{a}$ \\
Aplikasi & & & & \\
$\quad$ Mindi & $9,26 \mathrm{a}$ & $9,75 \mathrm{a}$ & $14,31 \mathrm{a}$ & $22,81 \mathrm{~b}$ \\
Sirsak & $9,26 \mathrm{a}$ & $9,26 \mathrm{a}$ & $13,57 \mathrm{a}$ & $24,17 \mathrm{ab}$ \\
$\quad$ Mahoni & $9,38 \mathrm{a}$ & $9,50 \mathrm{a}$ & $14,07 \mathrm{a}$ & $23,68 \mathrm{ab}$ \\
$\quad$ Kontrol & $9,63 \mathrm{a}$ & $10,00 \mathrm{a}$ & $14,57 \mathrm{a}$ & $25,41 \mathrm{a}$ \\
\hline
\end{tabular}

Keterangan : Huruf yang sama pada satu kolom menunjukkan data tidak berbeda nyata berdasarkan Duncan $5 \%$

Penyakit hawar pelepah mulai ditemukan pada umur padi 9 MST. Penyakit ini umumnya ditemukan pada pertanaman padi memasuki fase generatif karena rumpun padi cukup rimbun dan pengairan secara terus menerus menyebabkan iklim mikro diantara kanopi tanaman padi mendukung perkembangan penyakit ini. Keparahan penyakit hawar pelepah relatif lebih tinggi pada 9 MST ditemukan pada varietas Inpari 33, sedangkan pada 11 MST dijumpai pada varietas Sintanur. Keparahan hawar pelepah tidak berbeda nyata pada perlakuan varietas di semua waktu pengamatan. Keparahan hawar pelepah relatif lebih tinggi dijumpai pada plot perlakuan yang tidak diaplikasi oleh ekstrak daun pada 9 hingga 11 MST. Aplikasi ekstrak daun Mindi, sirsak, dan mahoni menunjukkan keparahan hawar pelepah yang berbeda nyata dengan tanpa aplikasi (Tabel 12).

Cercospora Leaf Spot (CLS) mulai ditemukan pada umur padi 9 MST. Menurut Ginting (2008), gejala serangan bercak coklat sempit (Cercospora oryzae) mulai 
tampak di lapangan setelah 5 MST. Intensitas serangan penyakit relatif lebih tinggi pada fase generatif. Hasil penelitian di lapangan menunjukkan keparahan penyakit CLS relatif lebih tinggi pada umur padi 9 MST dijumpai pada varietas Sintanur, sedangkan pada 11 MST dijumpai pada varietas Inpari 33. Pada umur padi $11 \mathrm{MST}$, keparahan penyakit CLS meningkat cukup pesat karena tanaman tidak diberikan pupuk sehingga penyakit ini mudah menyerang daun padi. Namun keparahan penyakit tidak berbeda nyata pada semua varietas padi di semua waktu pengamatan. Keparahan penyakit CLS relatif lebih rendah ditemukan pada plot yang diaplikasi ekstrak daun Mindi atau Sirsak, dan berbeda nyata dengan plot kontrol (Tabel 13).

Tabel 12. Keparahan Penyakit Hawar Pelepah Padi pada Budidaya Padi Organik, Sukamandi MK 2016

\begin{tabular}{lcccc}
\hline \multirow{2}{*}{ Perlakuan } & \multicolumn{4}{c}{ Keparahan Penyakit } \\
\cline { 2 - 5 } Varietas & $5 \mathrm{MST}$ & $7 \mathrm{MST}$ & $9 \mathrm{MST}$ & $11 \mathrm{MST}$ \\
$\quad$ Inpari 25 & - & - & & \\
Inpari 33 & - & - & $0,65 \mathrm{a}$ & $4,35 \mathrm{a}$ \\
Sintanur & - & - & $0,74 \mathrm{a}$ & $3,98 \mathrm{a}$ \\
Aplikasi & - & $0,37 \mathrm{a}$ & $3,70 \mathrm{a}$ \\
Mindi & - & - & $0,25 \mathrm{a}$ & $2,96 \mathrm{~b}$ \\
Sirsak & - & - & $0,49 \mathrm{a}$ & $3,08 \mathrm{~b}$ \\
Mahoni & - & - & $0,49 \mathrm{a}$ & $3,95 \mathrm{~b}$ \\
Kontrol & - & $1,11 \mathrm{a}$ & $6,05 \mathrm{a}$ \\
\hline
\end{tabular}

Keterangan : Huruf yang sama pada satu kolom menunjukkan data tidak berbeda nyata berdasarkan Duncan $5 \%$

Tabel 13. Keparahan Penyakit Cercospora Leaf Spot pada Budidaya Padi Organik, Sukamandi MK 2016

\begin{tabular}{lcccc}
\hline \multirow{2}{*}{ Perlakuan } & \multicolumn{4}{c}{ Keparahan Penyakit } \\
\cline { 2 - 5 } Varietas & $5 \mathrm{MST}$ & $7 \mathrm{MST}$ & $9 \mathrm{MST}$ & $11 \mathrm{MST}$ \\
$\quad$ Inpari 25 & $--\%--$ \\
Inpari 33 & - & - & $0,00 \mathrm{a}$ & $10,83 \mathrm{a}$ \\
Sintanur & - & - & $1,85 \mathrm{a}$ & $34,23 \mathrm{a}$ \\
Aplikasi & - & - & $3,80 \mathrm{a}$ & $22,57 \mathrm{a}$ \\
Mindi & - & - & $2,10 \mathrm{a}$ & $19,98 \mathrm{c}$ \\
Sirsak & - & - & $2,10 \mathrm{a}$ & $19,74 \mathrm{c}$ \\
Mahoni & - & - & $1,11 \mathrm{a}$ & $23,81 \mathrm{~b}$ \\
Kontrol & - & - & $2,22 \mathrm{a}$ & $26,64 \mathrm{a}$ \\
\hline
\end{tabular}

Keterangan : Huruf yang sama pada satu kolom menunjukkan data tidak berbeda nyata berdasarkan Duncan 5\%

Penyakit Bercak daun Cercospora sering dijumpai pada lahan yang miskin hara. Selain itu, penyakit ini dapat dijumpai pada varietas yang rentan terhadap patogen
Cercospora oryzae seperti varietas Ciherang. Tanaman padi dengan dosis pemupukan yang rendah dan tidak mencukupi kebutuhan hara tanaman 
banyak dijumpai serangan penyakit ini. Hal ini sejalan dengan pernyataan Suprihanto et al. (2009) bahwa tanaman padi menunjukkan reaksi paling rentan pada dosis pemupukan nitrogen yang paling rendah. Menurut Suganda et al. (2002), resistensi pada tanaman padi terhadap penyakit bercak daun Cercospora dapat diinduksi oleh berbagai perlakuan eksternal menggunakan bahan kimia penginduksi. Diantara bahan-bahan penginduksi yaitu asam salisilat, kitin asal kulit udang, dan $\mathrm{K}_{2} \mathrm{HPO}_{4}$ menghasilkan efek penginduksian yang sama dengan bahan penginduksi komersial (benzothizadiazole-mankozeb, Bion).

\section{Musuh Alami pada Padi}

Kepadatan populasi laba-laba relatif lebih tinggi pada umur padi 5 hingga 9 MST ditemukan pada varietas Inpari 25, sedangkan pada 11 MST ditemukan pada varietas Inpari 25 dan Inpari 33. Populasi laba-laba tidak berbeda nyata di semua varietas padi selama waktu pengamatan.
Populasi laba-laba dengan kepadatan relatif lebih tinggi dijumpai pada plot yang diaplikasi dengan ekstrak daun Sirsak pada umur padi 5 MST. Kepadatan populasi labalaba relatif lebih tinggi pada umur padi 7 MST dijumpai pada plot yang diaplikasi dengan ekstrak daun Mindi atau kontrol. Plot yang diaplikasi dengan ekstrak daun Sirsak atau Mahoni menunjukkan kepadatan populasi laba-laba relatif lebih tinggi pada 9 MST, sedangkan pada 11 MST dijumpai pada plot perlakuan kontrol (Tabel 14).

Kepadatan populasi laba-laba tidak berbeda nyata pada semua plot perlakuan aplikasi termasuk kontrol. $\mathrm{Hal}$ ini menunjukkan bahwa aplikasi ekstrak daun aman bagi musuh alami. Sejalan dengan pernyataan Nurhidayati et al. (2008) bahwa pengendalian OPT yang aman dan tidak menimbulkan pencemaran lingkungan adalah biopestisida karena bersumber pada bahan alami seperti tumbuhan, hewan, dan mikroba sehingga mudah terurai dan spesifik sasaran.

Tabel 14. Kepadatan Populasi Laba-Laba pada Budidaya Padi Organik, Sukamandi MK 2016

\begin{tabular}{|c|c|c|c|c|}
\hline \multirow{2}{*}{ Perlakuan } & \multicolumn{4}{|c|}{ Kepadatan Populasi } \\
\hline & $5 \mathrm{MST}$ & $7 \mathrm{MST}$ & $9 \mathrm{MST}$ & $11 \mathrm{MST}$ \\
\hline & \multicolumn{4}{|c|}{--ekor-- } \\
\hline \multicolumn{5}{|l|}{ Varietas } \\
\hline Inpari 25 & $19,00 \mathrm{a}$ & $17,58 \mathrm{a}$ & 18,29 a & $15,92 \mathrm{a}$ \\
\hline Inpari 33 & $17,83 \mathrm{a}$ & $16,83 \mathrm{a}$ & $17,33 \mathrm{a}$ & $15,92 \mathrm{a}$ \\
\hline Sintanur & $18,75 \mathrm{a}$ & $16,83 \mathrm{a}$ & 17,79 a & $15,00 \mathrm{a}$ \\
\hline \multicolumn{5}{|l|}{ Aplikasi } \\
\hline Mindi & $17,78 \mathrm{a}$ & $17,33 \mathrm{a}$ & $17,56 \mathrm{a}$ & $15,11 \mathrm{a}$ \\
\hline Sirsak & $19,44 a$ & $16,67 \mathrm{a}$ & 18,06 a & $15,78 \mathrm{a}$ \\
\hline Mahoni & $19,11 \mathrm{a}$ & $17,00 \mathrm{a}$ & $18,06 \mathrm{a}$ & $15,67 a$ \\
\hline Kontrol & $17,78 \mathrm{a}$ & $17,33 a$ & $17,56 \mathrm{a}$ & $15,89 a$ \\
\hline
\end{tabular}

Keterangan : Huruf yang sama pada satu kolom menunjukkan data tidak berbeda nyata berdasarkan Duncan 5\%

Secara umum trend populasi laba-laba cukup tinggi pada MK 2016 dan berfluktuasi selama pengamatan, namun kepadatan populasi cukup stabil. Aplikasi bioinsektisida padat dan cair mempengaruhi kelimpahan relatif laba-laba predator di 
tajuk tanaman padi di daerah pasang surut (Khodijah, 2014). Laba-laba jenis Pardosa pseudoannulata dan Tetragnatha maxillosa berpotensi tinggi menekan populasi Nilaparvata lugens dan intensitas serangan pada tanaman padi dengan kemampuan memangsa masing-masing 4,05 dan 3,10 ekor per hari. Intensitas serangan Nilaparvata lugens rendah bila kemampuan memangsa predator tinggi yaitu Pardosa pseudoannulata dan Tetragnatha masing-masing 17,05 dan 18,89\% (Marheni, 2004).

Kepadatan populasi Phaederus sp. relatif lebih tinggi pada umur padi 5 MST teridentifikasi pada varietas Inpari 25 atau Sintanur, sedangkan pada 7 hingga 11 MST dijumpai pada varietas Inpari 25. Populasi Phaederus sp. dengan kepadatan relatif lebih tinggi dijumpai pada plot yang diaplikasi dengan ekstrak daun Mindi pada 5 hingga 9 MST, sedangkan pada 11 MST dijumpai pada plot yang diaplikasi dengan ekstrak daun Mahoni (Tabel 15). Kepadatan populasi Phaederus sp. tidak berbeda nyata pada perlakuan varietas maupun aplikasi ekstak daun pada semua waktu pengamatan.

Tabel 15. Kepadatan populasi Phaederus sp. pada budidaya padi organik, Sukamandi MK 2016.

\begin{tabular}{lcccc}
\hline \multirow{2}{*}{ Perlakuan } & \multicolumn{5}{c}{ Kepadatan Populasi (ekor) } \\
\cline { 2 - 5 } Varietas & $5 \mathrm{MST}$ & \multicolumn{4}{c}{ - $\mathrm{MST}$} & $\mathrm{MST}$ & $11 \mathrm{MST}$ \\
$\quad$ Inpari 25 & $2,67 \mathrm{a}$ & $1,25 \mathrm{a}$ & $1,96 \mathrm{a}$ & $1,17 \mathrm{a}$ \\
$\quad$ Inpari 33 & $1,75 \mathrm{a}$ & $1,17 \mathrm{a}$ & $1,46 \mathrm{a}$ & $0,92 \mathrm{a}$ \\
$\quad$ Sintanur & $2,67 \mathrm{a}$ & $0,92 \mathrm{a}$ & $1,80 \mathrm{a}$ & $0,83 \mathrm{a}$ \\
Aplikasi & & & & \\
$\quad$ Mindi & $3,00 \mathrm{a}$ & $1,33 \mathrm{a}$ & $2,17 \mathrm{a}$ & $1,00 \mathrm{a}$ \\
$\quad$ Sirsak & $2,67 \mathrm{a}$ & $1,22 \mathrm{a}$ & $1,95 \mathrm{a}$ & $1,00 \mathrm{a}$ \\
$\quad$ Mahoni & $1,89 \mathrm{a}$ & $0,89 \mathrm{a}$ & $1,39 \mathrm{a}$ & $1,22 \mathrm{a}$ \\
$\quad$ Kontrol & $1,89 \mathrm{a}$ & $1,00 \mathrm{a}$ & $1,45 \mathrm{a}$ & $0,67 \mathrm{a}$ \\
\hline
\end{tabular}

Keterangan : Huruf yang sama pada satu kolom menunjukkan data tidak berbeda nyata berdasarkan Duncan 5\%

\section{Bagan Warna Daun}

Hasil pengamatan pada MH 2015/2016 menunjukkan varietas Sintanur memiliki nilai Bagan Warna Daun (BWD) relatif lebih tinggi dibandingkan varietas lainnya. Nilai BWD tidak berbeda nyata pada semua varietas pada umur padi 7 MST. Namun nilai BWD berbeda nyata antara varietas Sintanur dengan Inpari 33 pada umur padi 9 MST. Plot yang diaplikasi dengan ekstrak daun Sirsak menunjukkan BWD relatif lebih tinggi pada umur padi 7 MST, sedangkan pada 9 MST dijumpai pada plot yang diaplikasi ekstrak daun Mindi. Nilai BWD pada plot yang diaplikasi ekstrak Mindi, Sirsak, dan Mahoni berbeda nyata dengan plot kontrol (Tabel 16).

Hasil pengamatan pada MK 2016 menunjukkan varietas Sintanur memiliki nilai BWD relatif lebih tinggi dibandingkan varietas lainnya pada umur padi 7 hingga 9MST. Namun nilai BWD tidak berbeda nyata pada semua varietas pada semua waktu pengamatan. Plot perlakuan yang diaplikasi dengan ekstrak daun Mahoni menunjukkan nilai BWD relatif lebih tinggi 
pada umur padi 7 MST, sedangkan pada 9 MST dijumpai pada plot perlakuan yang diaplikasi dengan ekstrak daun Sirsak (Tabel 17). Nilai BWD tidak berbeda nyata pada semua perlakuan aplikasi pada semua waktu pengamatan.

BWD diadopsi di India rata-rata 57 hingga $63 \%$ dari lahan padi. Adopsi BWD dapat mengurangi penggunaan $\mathrm{N}$ sebesar $25 \mathrm{~kg} \mathrm{ha}^{-1}(19,4 \%)$, dengan pengurangan tertinggi sebesar $31,4 \mathrm{~kg} \mathrm{ha}^{-1}(21,0 \%) \mathrm{di}$ musim bera. Adopsi BWD dapat me- ngurangi aplikasi insektisida dengan 50\%. Penggunaan pupuk $\mathrm{N}$ secara bijaksana membuat tanaman menjadi lebih tahan terhadap hama tertentu. Efek gabungan dari berkurangnya penggunaan pupuk $\mathrm{N}$ dan insektisida memiliki efek perlindungan terhadap lingkungan yang cukup besar untuk diadopsi di daerah yang lebih luas. Usia petani, pendidikan, dan pengalaman dalam bertani adalah faktor penentu utama adopsi BWD (Islam et al., 2007).

Tabel 16. Bagan Warna Daun pada Budidaya Padi Organik, Sukamandi MH 2015/2016

\begin{tabular}{lcccc}
\hline \multirow{2}{*}{ Perlakuan } & \multicolumn{4}{c}{ Nilai Warna } \\
\cline { 2 - 5 } & $5 \mathrm{MST}$ & $7 \mathrm{MST}$ & $9 \mathrm{MST}$ & $11 \mathrm{MST}$ \\
\hline Varietas & & & & \\
Inpari 25 & - & $2,56 \mathrm{a}$ & $2,58 \mathrm{ab}$ & - \\
Inpari 33 & - & $2,23 \mathrm{a}$ & $2,50 \mathrm{~b}$ & - \\
$\quad$ Sintanur & - & $2,63 \mathrm{a}$ & $2,72 \mathrm{a}$ & - \\
Aplikasi & - & $2,48 \mathrm{a}$ & $2,80 \mathrm{a}$ & - \\
$\quad$ Mindi & - & $2,52 \mathrm{a}$ & $2,62 \mathrm{~b}$ & - \\
Sirsak & - & $2,42 \mathrm{a}$ & $2,73 \mathrm{ab}$ & - \\
Mahoni & - & $2,47 \mathrm{a}$ & $2,24 \mathrm{c}$ & - \\
$\quad$ Kontrol & - & &
\end{tabular}

Keterangan : Huruf yang sama pada satu kolom menunjukkan data tidak berbeda nyata berdasarkan Duncan 5\%

Tabel 17. Bagan Warna Daun pada Budidaya Padi Organik, Sukamandi MK 2016

\begin{tabular}{lcccc}
\hline \multirow{2}{*}{ Perlakuan } & \multicolumn{4}{c}{ Nllai Warna } \\
\cline { 2 - 5 } & $5 \mathrm{MST}$ & $7 \mathrm{MST}$ & $9 \mathrm{MST}$ & $11 \mathrm{MST}$ \\
\hline Varietas & & $3,37 \mathrm{a}$ & $3,00 \mathrm{a}$ & - \\
$\quad$ Inpari 25 & - & $2,86 \mathrm{~b}$ & $3,10 \mathrm{a}$ & - \\
$\quad$ Inpari 33 & - & $3,39 \mathrm{a}$ & $3,18 \mathrm{a}$ & - \\
$\quad$ Sintanur & - & & & - \\
Aplikasi & - & $3,23 \mathrm{a}$ & $3,09 \mathrm{a}$ & - \\
$\quad$ Mindi & - & $3,17 \mathrm{a}$ & $3,16 \mathrm{a}$ & - \\
Sirsak & - & $3,29 \mathrm{a}$ & $3,07 \mathrm{a}$ & - \\
Mahoni & - & $3,13 \mathrm{a}$ & $3,07 \mathrm{a}$ & - \\
$\quad$ Kontrol & - & &
\end{tabular}

Keterangan : Huruf yang sama pada satu kolom menunjukkan data tidak berbeda nyata berdasarkan Duncan 5\%

Varietas dan aplikasi ekstrak daun masing-masing berpengaruh nyata pada keparahan penyakit busuk batang pada umur padi 5 dan 7 MST pada $\mathrm{MH}$ 2015/2016 (Tabel 1). Pada musim hujan ditemukan gejala Yellowing karena awal 
peralihan cara budidaya konvesional ke budidaya organik terlihat pada varietas unggul baru seperti Inpari 25 dan Inpari 33. Namun varietas Sintanur lebih tahan terhadap gejala Yellowing ditunjukkan dengan nilai BWD pada musim hujan dan musim kemarau relatif lebih tinggi dibandingkan varietas lainnya (Tabel 16 dan 17). Selain itu, varietas Sintanur menunjukkan keparahan penyakit CLS relatif lebih rendah dibandingkan varietas lainnya (Tabel 4 dan 13). Keparahan penyakit umumnya meningkat seiring dengan bertambahnya umur tanaman padi, sedangkan kepadatan populasi hama dan musuh alami relatif berfluktuasi.

Hasil penelitian menunjukkan perlakuan varietas menunjukkan kepadatan populasi hama dan musuh alami maupun keparahan penyakit tidak berbeda nyata pada semua waktu pengamatan. Perlakuan aplikasi ekstrak daun pestisida nabati menunjukkan kepadatan populasi hama cukup tinggi pada plot perlakuan kontrol, sedangkan kepadatan populasi musuh alami cukup tinggi pada plot perlakuan yang diaplikasi ekstrak daun Mindi, Mahoni, dan Sirsak. Hal ini sejalan dengan penelitian Widiarta et al. (2006), bahwa cara budidaya organik merupakan habitat yang baik bagi musuh alami, meskipun kelimpahan populasinya lebih rendah dari pengelolaan tanaman terpadu. Namun indeks keanekaragaman organisme pada lahan organik lebih tinggi dibandingkan dengan lahan dikelola secara konvensional (Pradhana et al., 2014).

Keberhasilan pengembangan pertanian organik akan terwujud ketika ada dukungan dari pemerintah baik dalam bentuk pelatihan, modal produksi serta regulasi masing-masing tingkat Pemerintah Daerah. Keberhasilan untuk meningkatkan kesejahteraan petani juga akan diiringi oleh kecintaan lingkungan hidup, karena akan terciptanya lingkungan yang sehat, asri, alami yang akan mendorong ke dalam pertanian hijau. Pengembangan selanjutnya pertanian organik di Indonesia harus ditujukan untuk memenuhi permintaan pasar global (Mayrowani, 2012).

\section{SIMPULAN}

Varietas dan aplikasi ekstrak daun pestisida nabati masing-masing berpengaruh nyata pada keparahan penyakit busuk batang pada umur padi 5 dan 7 MST pada musim hujan 2015/2016. Pada musim hujan ditemukan gejala Yellowing karena awal peralihan cara budidaya konvesional ke budidaya organik terlihat pada varietas unggul baru seperti Inpari 25 dan Inpari 33. Namun varietas Sintanur lebih tahan terhadap gejala Yellowing ditunjukkan dengan nilai bagan warna daun pada musim hujan dan musim kemarau relatif lebih tinggi dibandingkan varietas lainnya. Selain itu, Sintanur menunjukkan keparahan penyakit Cercospora leaf spot relatif lebih rendah dibandingkan dengan varietas lainnya. Keparahan penyakit umumnya meningkat seiring dengan bertambahnya umur tanaman padi, sedangkan kepadatan populasi hama dan musuh alami berfluktuasi. Kepadatan populasi hama cukup tinggi pada plot perlakuan kontrol, sedangkan kepadatan populasi musuh alami cukup tinggi pada plot perlakuan aplikasi ekstrak tanaman yang mengandung efek pestisida seperti Mindi, Mahoni, dan Sirsak.

\section{DAFTAR PUSTAKA}

Atmojo SW. 2003. Peranan bahan organik terhadap kesuburan tanah dan upaya 
pengelolaannya. Pidato Pengukuhan Guru Besar Ilmu Kesuburan Tanah. Fakultas Pertanian. Surakarta: Universitas Sebelas Maret. $36 \mathrm{Hal}$.

Baehaki SE. 2011. Normalisasi dan pengendalian dini hama wereng cokelat pengamanan produksi padi nasional. Sinar Tani Edisi 20-26 Juli 2011 No. 3415 Tahun XLI. 9 Hal.

Djazuli M. 2014. Pupuk organik dalam sistem pertanian organik di Indonesia. Dalam Buku Prinsip-prinsip dan Teknologi Pertanian Organik. Kardinan A (editor). IAARD Press: Badan Penelitian dan Pengembangan Pertanian. Kementerian Pertanian. Hal: 93-98.

Ginting MS. 2008. Intensitas serangan penyakit penyakit bercak coklat sempit (Cercospora oryzae) (Rocib) O. Const pada beberapa varietas padi sawah (Oryza sativa L.) dengan jarak tanam yang berbeda di lapangan. [Skripsi]. Medan: Departemen Hama dan Penyakit Tanaman. Fakultas Pertanian. Universitas Sumatera Utara. $54 \mathrm{Hal}$.

Gomez KA, dan Gomez AA. 1995. Prosedur statistik untuk penelitian pertanian. Endang S. \& Justika S.B. (Terjemahan). Jakarta: UI-Press. 698 hal.

Gribaldi. 2009. Pertanian organik dan teknologi pendukungnya. Agronobis 1 (2): 19-24.

Hadisuwito S. 2008. Membuat pupuk kompos cair. Jakarta: PT. Agromedia Pustaka. $50 \mathrm{Hal}$.

IRRI. 2014. Standart evaluation system for rice. IRTP. IRRI. $5^{\text {ed }}$. Los Banos, Philippines. 57p.

Islam Z, Bagchi B, and Hossain M. 2007. Adoption of leaf color chart for nitrogen use efficiency in rice: Impact assessment of a farmer-participatory experiment in West Bengal, India. Field Crops Research 103: 70-75.
Ismawati. 2012. Perkembangan populasi kepinding tanah Scotinophara coarctata (Fabricus) (Hemiptera: Pentatomidae) pada pertanaman padi. [Skripsi]. Bogor: Departemen Proteksi Tanaman. Fakultas Pertanian. Institut Pertanian Bogor. 45 hal.

Khodijah. 2014. Kelimpahan relatif laba-laba predator di tajuk tanaman padi yang diaplikasikan bioinsektisida di daerah pasang surut. Jurnal IImiah Agriba 2: 122-129.

Laba IW, dan Willis M. 2014. Pemanfaatan musuh alami dalam pengendalian organisme pengganggu tanaman pada sistem pertanian organik. Dalam Buku Prinsip-prinsip dan Teknologi Pertanian Organik. Kardinan A (editor). IAARD Press: Badan Penelitian dan Pengembangan Pertanian. Kementerian Pertanian. Hal: 33-40.

Marheni. 2004. Kemampuan beberapa predator pada pengendalian wereng batang cokelat (Nilaparvata lugens Stal.). Jurnal Natur Indonesia 6 (2): 84-86.

Mayrowani H. 2012. Pengembangan pertanian organik di Indonesia. Forum Penelitian Agro Ekonomi 30 (2): 91-108.

Nasahi C. 2010. Peran mikroba dalam pertanian organik. Jurusan Hama dan Penyakit Tumbuhan. Fakultas Pertanian. Universitas Padjadjaran. Bandung. 78 Hal.

Nurhidayati, Pujiwati I, Solichah A, Djuhari, dan Basit A. 2008. E-Book pertanian organik: suatu kajian sistem pertanian terpadu dan berkelanjutan. Program Studi Agroteknologi. Jurusan Budidaya Pertanian. Fakultas Pertanian. Universitas Islam Malang. $196 \mathrm{HIm}$.

Pradhana RAI, Mudjiono G, dan Karindah S. 2014. Keanekaragaman serangga dan laba-laba pada pertanaman padi organik dan konvensional. Jurnal HPT 2 (2): 5866. 
Roidah IS. 2013. Manfaat penggunaan pupuk organik untuk kesuburan tanah. Jurnal Universitas Tulungagung Bonorowo 1 (1): 30-42.

Suganda T, Rismawati E, Yulia E, dan Nasahi C. 2002. Pengujian kemampuan beberapa bahan kimia dan air perasan daun tumbuhan dalam menginduksi resistensi tanaman padi terhadap penyakit bercak daun cercospora. Jurnal Bionatura 4 (1): 17-28.

Suprihanto, Guswara A, dan Satoto. 2009. Pengaruh dosis pupuk nitrogen terhadap beberapa penyakit pada varietas padi hibrida. Prosiding Seminar Nasional Padi 2008. Balai Besar Penelitian Tanaman Padi. Kementerian Pertanian. Hal 445451.
Tangkilisan VE, Salaki CL, Dien MF, dan Meray ERM. 2013. Serangan hama putih palsu Cnaphalocrosis medinalis GUENEE. pada tanaman padi sawah di Kecamatan Ranoyapo Kabupaten Minahasa Selatan. Eugenia 19 (3): 23-29.

Widiarta IN, Kusdiaman D, dan Suprihanto. 2006. Keragaman arthropoda pada padi sawah dengan pengelolaan tanaman terpadu. Jurnal HPT Tropika 6 (2): 61-69.

Widiarta A. 2011. Analisis keberlanjutan praktik pertanian organik di kalangan petani. Departemen Sains Komunikasi dan Pengembangan Masyarakat. [Skripsi]. Bogor (ID): Fakultas Ekologi Manusia. Institut Pertanian Bogor. 160 Hal. 